\title{
Reptilian Diversity of the Bhopal Region in the State of Madhya Pradesh in Central India
}

\author{
Amit Manhas ${ }^{1 *}$, Rajni Raina ${ }^{2}$, and Ashwani Wanganeo ${ }^{1}$ \\ ${ }^{1}$ Department of Environmental Sciences and Limnology, Barkatullah University, Bhopal, Madhya Pradesh, India (amitmanhas1986@gmail.com) \\ ${ }^{2}$ Department of Zoology, Government Science and Commerce College, Bhopal, Madhya Pradesh, India
}

Photographs by the senior author.

\begin{abstract}
The wide range of habitats in the Bhopal Region of Madhya Pradesh in central India support a rich reptilian fauna. Conducting visual surveys, we recorded 34 species of reptiles (2 species of crocodilians, 3 species of turtles, 13 species of lizards, 16 species of snakes). Observations were made during the monsoon period from mid-June to mid-September in 2014-2015. Herein, we present baseline data regarding the reptilian fauna of the Bhopal Region.
\end{abstract}

$\mathrm{R}$ eptiles comprise a significant component of Earth's biodiversity, but populations of many species are declining, with habitat destruction the principal cause (e.g., Gibbons et al. 2000; Krauss et al. 2010; Manhas et al. 2016a). India is home to more than 500 reptilian species in 28 families. These include 279 species of snakes, 202 species of lizards, 34 species of turtles and tortoises, and three species of crocodiles (Aengals et al. 2011). In the state of Madhya Pradesh, Kalalurasam et al. (1991) documented 21 species of reptiles from the Narmada Valley, Sanyal (1995) recorded 12 species from the Indrāvati Tiger Reserve, and Rao (1998) listed nine species from the
Chambal River, Pasha et al. (2000) reported nineteen species of snakes from Pench National Park, Ingle (2002) documented 30 species of snakes from the Malwa region, Chandra and Gajbe (2003) recorded the presence of Uropeltis ocellata from the Pachmarhi Biosphere Reserve, Chandra and Gajbe (2005) listed 76 species of reptiles from different parts of the state, Chandra (2009) documented eight species of snakes in six families from the Pachmarhi Biosphere Reserve, and Fellows (2014) recorded 31 species of snakes in six families from the Satpura Tiger and Pachmarhi Biosphere Reserves. In the city of Bhopal, Manhas et al. (2015a) recorded 16 species

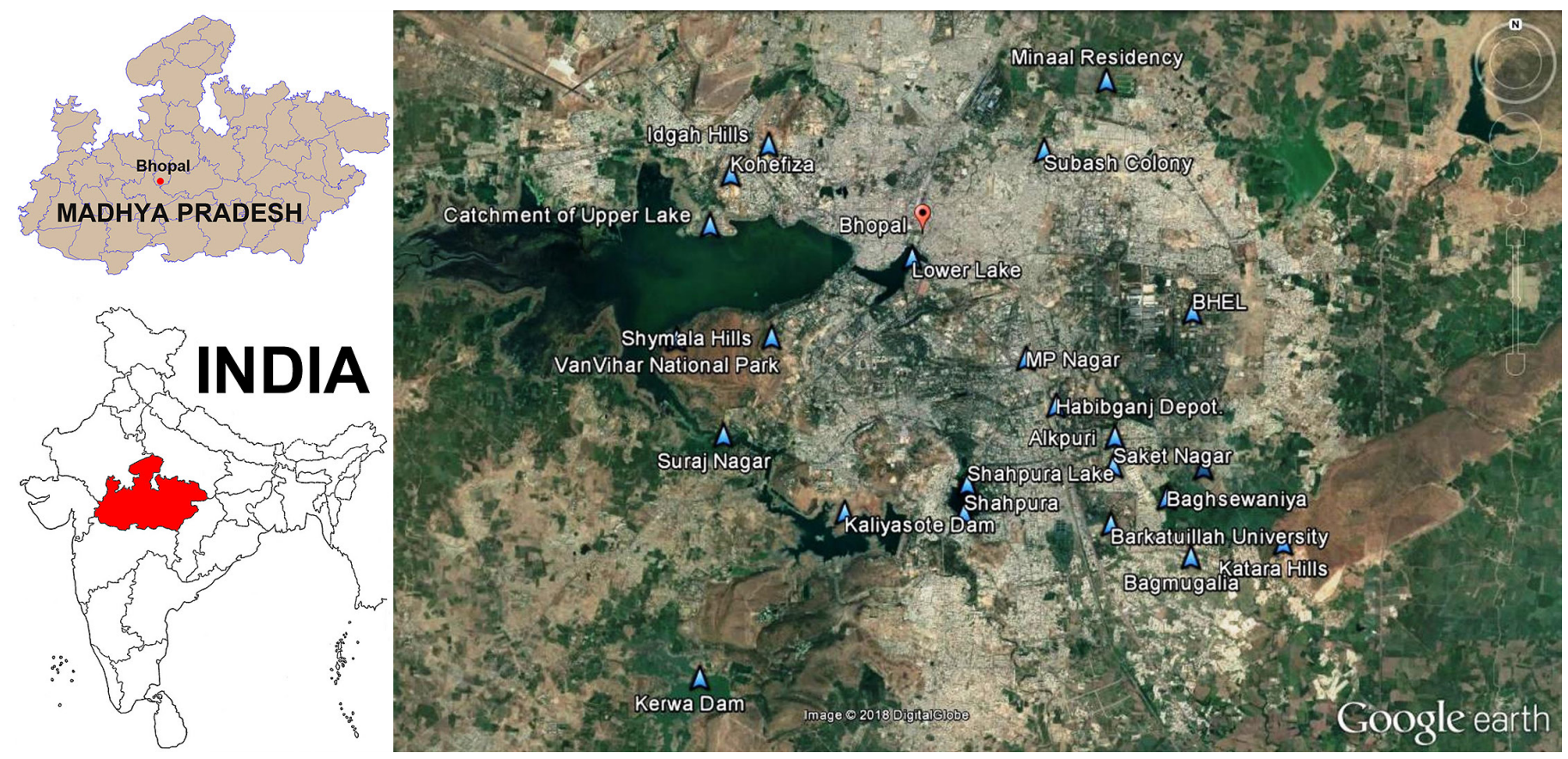

Fig. 1. Google Earth ${ }^{\odot}$ map of the Bhopal District, Madhya Pradesh, India showing sampling sites. 
of reptiles from the Barkatullah University campus, Manhas et al. (2015b) provided mortality data for 17 species of snakes, Manhas et al. (2016a) studied 40 individual Indian Ratsnakes (Ptyas mucosa), and Manhas et al. (2016b) documented an increase in the number of reptilian species from the university campus to 22. Herein we provide a list of 34 species of reptiles from the Bhopal District with the intention that these data serve as a baseline for future studies in the region.

\section{Methods}

Bhopal $\left(23^{\circ} 14,01^{\prime \prime} \mathrm{N}, 77^{\circ} 23,36^{\prime \prime} \mathrm{E}\right.$; average elevation $527 \mathrm{~m}$ asl) is the capital of the state of Madhya Pradesh in central India (Fig. 1); it is known as the "city of lakes" because of its many natural and artificial lakes. The climate is subtropical with warm summers and a humid monsoon season. Summers extend from late March until mid-June, with temperatures averaging $-30{ }^{\circ} \mathrm{C}$ but regularly exceeding $40{ }^{\circ} \mathrm{C}$ during the peak of summer in May. The monsoon season extends from late June through late September.

We conducted visual field surveys in and around Bhopal during the monsoon periods (mid-June to mid-September) in two consecutive years (2014-2015). We made most observations by day (mostly in the morning), but conducted nocturnal surveys whenever possible and included opportunistic sightings at any time. We collected no specimens during the study. We photographed animals using a digital camera (Sony HX-300), recorded localities using GPS coordinates, and identified species using the available literature (e.g., Smith 1931, 1935, 1943; Daniel 2002; Whitaker and Captain 2004). Subsequently, we determined the conservation status of each species by consulting the IUCN Red List of Threatened species (version 2017-3) and the Wildlife Act of India, 1972.

\section{Results}

We encountered 34 species of reptiles (2 species of crocodilians, 3 species of turtles, 13 species of lizards, and 16 species of snakes) in 14 families during the study period. Details for each species are listed below. IUCN Red List status (IUCN 2017) is NE (Not Evaluated), LC (Least Concern), VU (Vulnerable), EN (Endangered), and CR (Critically Endangered).
Mugger Crocodile, Crocodylus palustris (Lesson 1831) (Crocodylidae) VU - We recorded this species from the catchment area of the Upper Lake, including VanVihar National Park, and the Kaliyasote Dam. All observations were of basking individuals in July-September 2014 and 2015 at elevations of $497-512 \mathrm{~m}\left(23^{\circ} 11^{\prime} 40.90^{\prime \prime}-23^{\circ} 15^{\prime} 24.60^{\prime \prime} \mathrm{N}\right.$, $77^{\circ} 21^{\prime} 37.89^{\prime \prime}-77^{\circ} 23^{\prime} 48.79^{\prime \prime} \mathrm{E}$ ) and ambient air temperatures of $21-29^{\circ} \mathrm{C}$.

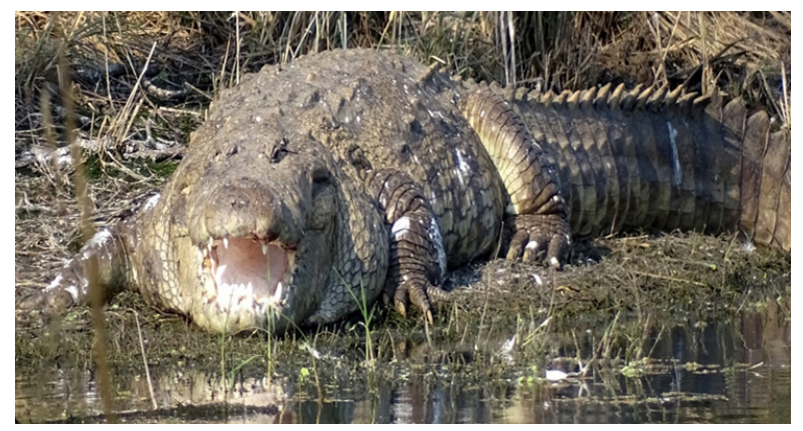

Vyas and Singh (2004) recorded this species from the Gandhisagar Reservoir and Chandra and Gajbe (2005) reported it from Jabalpur, Shivpuri, and Seoni. Ramakrishna et al. (2006) and Meshram (2010) documented the species in Pench, Madhav, and Satpura National Parks, and Meshram (2010) recorded it in the National Chambal Sanctuary. Taigor and Rao (2010) noted the presence of this species in the Chambal River.

Gharial, Gavialis gangeticus (Gmelin in Linnaeus 1789) (Gavialidae) CR - We observed individuals of this spe- cies basking in the catchment area of the Upper Lake, including VanVihar National Park, in August-September 2014 and 2015 at elevations of 511-512 m (23'13'15.40"$\left.23^{\circ} 15^{\prime} 28.00^{\prime \prime} \mathrm{N}, 77^{\circ} 21^{\prime} 47.20^{\prime \prime}-77^{\circ} 21^{\prime} 59.24^{\prime \prime} \mathrm{E}\right)$ and air temperatures of $23-27^{\circ} \mathrm{C}$.

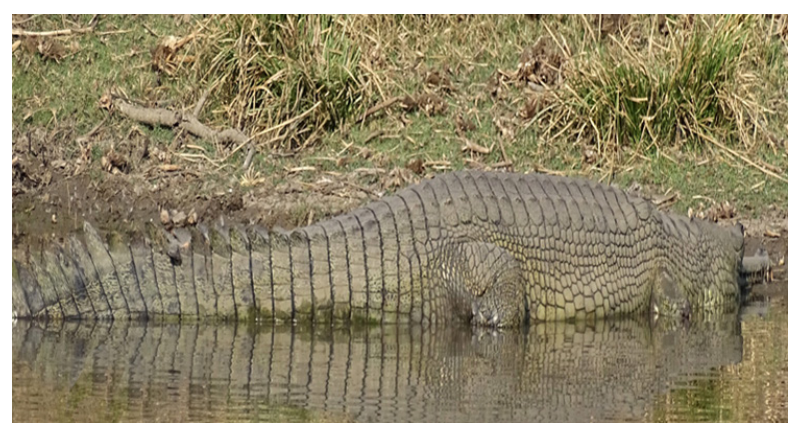

Chandra and Gajbe (2005) listed the species as occurring in Madhya Pradesh, and Meshram (2010) reported it from the National Chambal Sanctuary. Taigor and Rao (2010) noted the presence of this species in the Chambal River.

Indian Flap-shelled Turtle, Lissemys punctata (Bonnaterre 1789) (Trionychidae) LC - We recorded this species from the catchment area of the Lower Lake, Shahpura, Kerwa Dam, and the Upper Lake, including VanVihar National Park in July 2014 and June-September 2015 at elevations of $493-526 \mathrm{~m}\left(23^{\circ} 09^{\prime} 42.22^{\prime \prime}-23^{\circ} 15^{\prime} 35.05^{\prime \prime} \mathrm{N}, 77^{\circ} 21^{\prime} 43.38^{\prime \prime}-\right.$ $\left.77^{\circ} 25^{\prime} 7.59^{\prime \prime} \mathrm{E}\right)$ and air temperatures of $22-33^{\circ} \mathrm{C}$.

Vyas and Singh (2004) recorded the species from the Gandhisagar Reservoir. Chandra and Gajbe (2005) reported it 


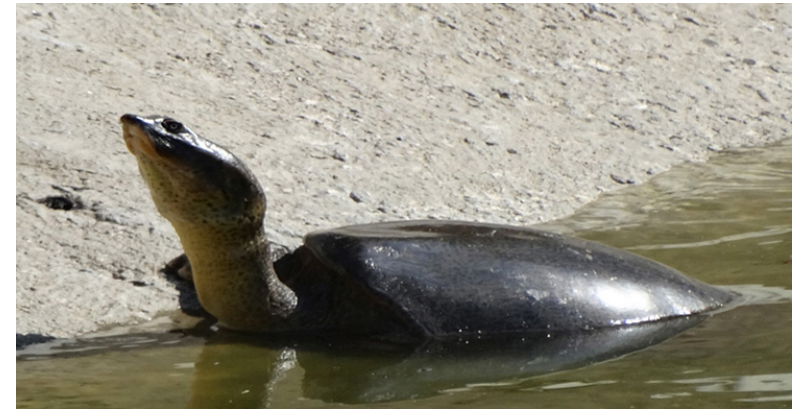

from the Seoni and Shivpuri Districts. Ramakrishna et al. (2006) found the species in Pench and Madhav National Parks, and Chandra et al. (2008) found it in the Kanha Tiger Reserve. Taigor and Rao (2010) noted the presence of this species in the Chambal River.

Indian Peacock Soft-shelled Turtle, Nilssonia hurum (Gray 1830) (Trionychidae) VU - We observed individuals of this species basking in July-September 2014 and 2015 in VanVihar National Park at an elevation of $517 \mathrm{~m}$ $\left(23^{\circ} 14^{\prime} 7.59^{\prime \prime} \mathrm{N}, 77^{\circ} 21^{\prime} 23.51^{\prime \prime} \mathrm{E}\right)$ and ambient temperatures of $24-30^{\circ} \mathrm{C}$.

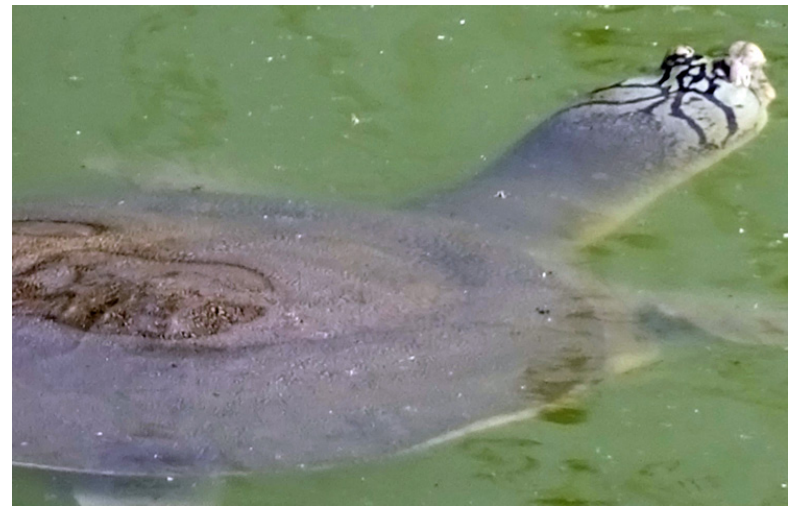

Das (1988) and Chandra and Gajbe (2005) reported this species from Bhopal.

Indian Roofed Turtle, Pangshura tecta (Gray 1830) (Trionychidae) LC - We observed this species at Van Vihar National Park, the Shahpura Lake, and from the catchment area of the Upper Lake in June-August 2014 and 2015 at elevations

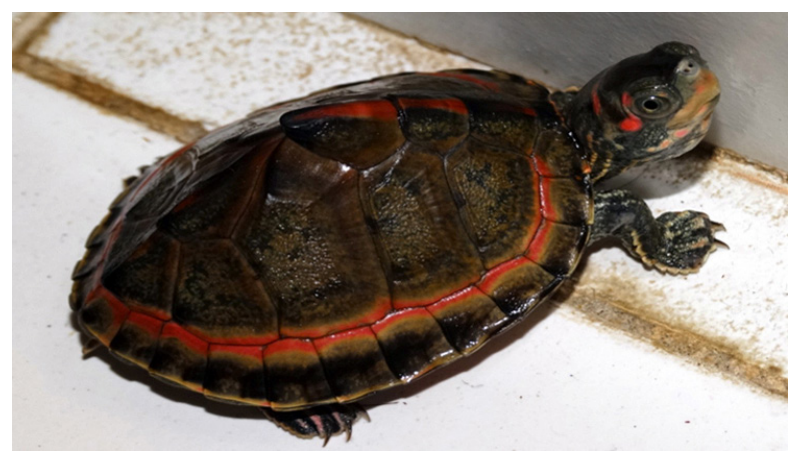

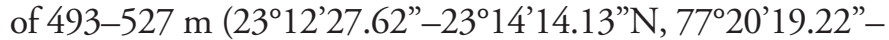
$\left.77^{\circ} 25^{\prime} 24.67^{\prime \prime} \mathrm{E}\right)$ and air temperatures of $20-30^{\circ} \mathrm{C}$.

Taigor and Rao (2010) documented the species from the Chambal River.

Brook's House Gecko, Hemidactylus brookii Gray 1845 (Gekkonidae) NE - We recorded this species from the campus of Barkatullah University, the Shymala Hills, BHEL, and the Subhash Colony in June-September 2014 and 2015 at elevations of $480-584 \mathrm{~m}\left(23^{\circ} 12^{\prime} 0.55^{\prime \prime}-23^{\circ} 15^{\prime} 31.81^{\prime \prime} \mathrm{N}\right.$, $\left.77^{\circ} 22^{\prime} 40.57^{\prime \prime}-77^{\circ} 27^{\prime} 51.62^{\prime \prime} \mathrm{E}\right)$ and ambient temperatures of $20-37^{\circ} \mathrm{C}$.

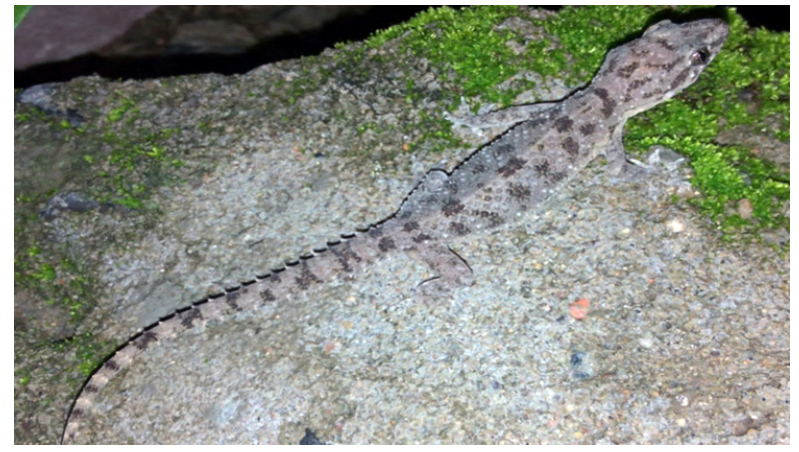

Chandra and Gajbe (2005) documented the species from various areas in Madhya Pradesh (Balaghat, Dindori, Jabalpur, Morena, Seoni, Shivpuri). Ramakrishna et al. (2006) recorded individuals in Pench and Kanha National Parks. Chandra et al. (2008) found it in the Kanha Tiger Reserve.

Yellow-Green House Gecko, Hemidactylus flaviviridis Rüppell 1835 (Gekkonidae) NE - We observed individuals of this species at Saket Nagar, Barkatullah University, BHEL, and the catchment area of the Upper Lake in JuneSeptember 2014 and 2015 at elevations of $483-528 \mathrm{~m}$ $\left(23^{\circ} 12^{\prime} 4.87^{\prime \prime}-23^{\circ} 15^{\prime} 31.56^{\prime \prime} \mathrm{N}, 77^{\circ} 27^{\prime} 16.58^{\prime \prime}-77^{\circ} 28^{\prime} 4.30^{\prime \prime} \mathrm{E}\right)$ and air temperatures of $19-32^{\circ} \mathrm{C}$.

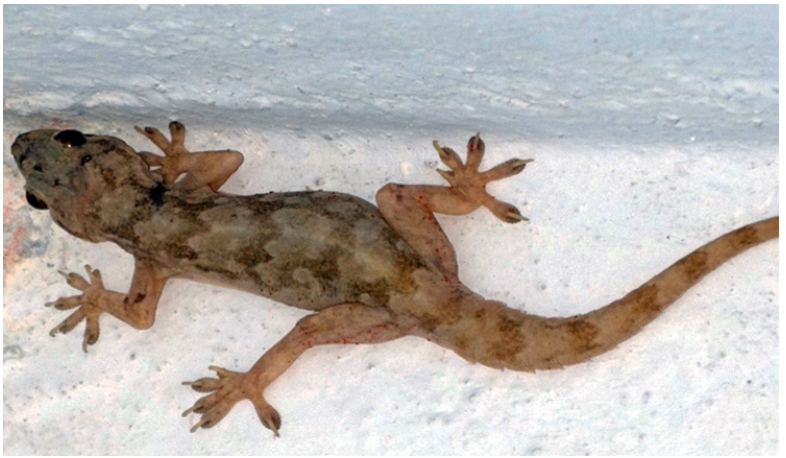

Chandra and Gajbe (2005) recorded this species from various areas in Madhya Pradesh (Balaghat, Jabalpur, Morena, Shivpuri). Ramakrishna et al. (2006) found it in the Kanha, Madhav, and Van Vihar National Parks, and Chandra et al. (2008) documented its presence in the Kanha Tigre Reserve. 
South Asian House Gecko, Hemidactylus frenatus Duméril and Bibron 1836 (Gekkonidae) LC - We recorded this species from the Barkatullah University, Saket Nagar, the Shymala Hills, and BHEL in June-September 2014 and 2015 at elevations of 482-604 m (23 $12^{\circ} 22.80^{\prime \prime}-$ $23^{\circ} 14^{\prime} 08.41^{\prime \prime} \mathrm{N}, 77^{\circ} 22^{\prime} 47.48^{\prime \prime}-77^{\circ} 28^{\prime} 10.47^{\prime \prime} \mathrm{E}$ ) and ambient air temperatures of $19-29^{\circ} \mathrm{C}$.

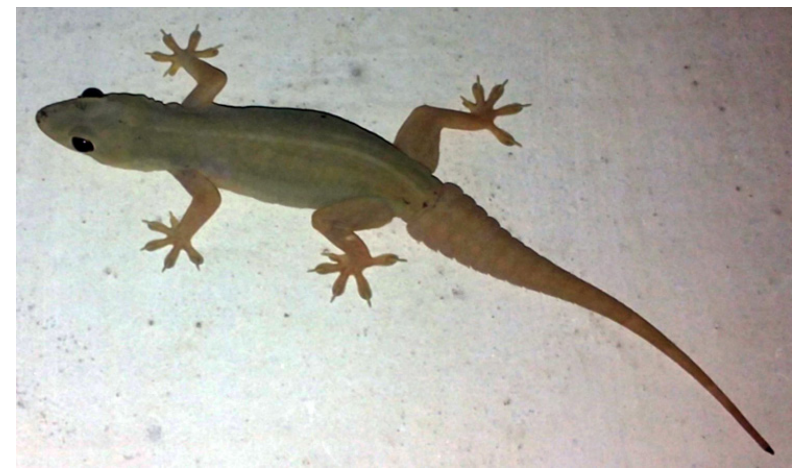

Uetz et al. (2018) listed a worldwide occurrence of this species in tropical and subtropical regions.

House Gecko, Hemidactylus sp. (Gekkonidae) - We encountered House Geckos that we were unable to identify to species in the Shymala Hills and at Saket Nagar in

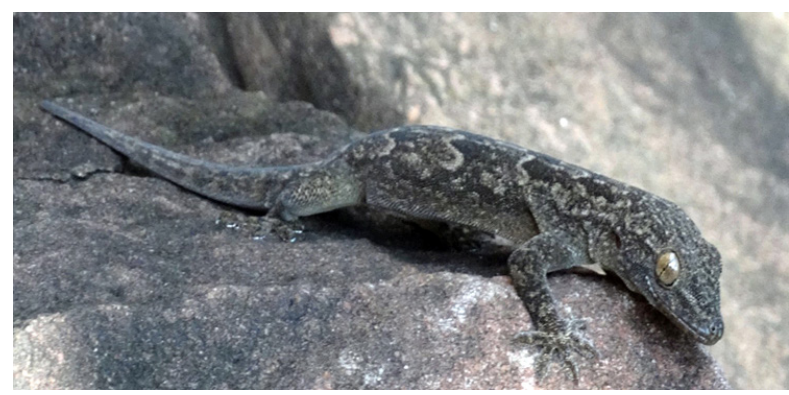

June 2014 and September 2015 at elevations of 489-604 m $\left(23^{\circ} 12^{\prime} 32.66^{\prime \prime}-23^{\circ} 14^{\prime} 8.41^{\prime \prime} \mathrm{N}, 77^{\circ} 22^{\prime} 47.48^{\prime \prime}-77^{\circ} 27^{\prime} 3.89^{\prime \prime} \mathrm{E}\right)$ and ambient temperatures of $29-32^{\circ} \mathrm{C}$.

Indian Garden Lizard, Calotes cf. versicolor (Daudin 1802 (Agamidae) NE - We observed this species at the Barkatullah University, Saket Nagar, Shahpura, Nagar, BHEL, Katra

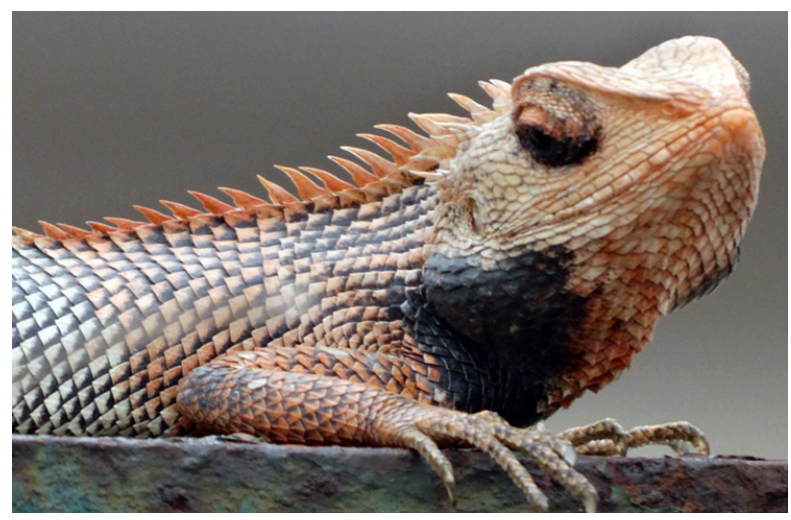

Hills, and Shymala Hills in June-September 2014 and 2015 at elevations of $471-563 \mathrm{~m}\left(23^{\circ} 11^{\prime} 26.67^{\prime \prime}-23^{\circ} 16^{\prime} 27.85^{\prime \prime} \mathrm{N}\right.$, $77^{\circ} 23^{\prime} 07.24^{\prime \prime}-77^{\circ} 29^{\prime} 2.21^{\prime \prime} \mathrm{E}$ ) and air temperatures of $20-30^{\circ} \mathrm{C}$.

Chandra and Gajbe (2005) recorded this species from throughout Madhya Pradesh (Balaghat, Dindori, Jabalpur, Morena, Shivpuri, and Hoshangabad). Ramakrishna et al. (2006) found it in Kanha, Madhav, Bandhavgarh, and VanVihar National Parks. Chandra et al. (2008) reported it from the Kanha Tigre Reserve.

Indian Chameleon, Chamaeleo zeylanicus (Laurenti 1768) (Chamaeleonidae) LC - We observed this species near Raja Bhoj Setu (Suraj Nagar) at an elevation of $515 \mathrm{~m}$ $\left(23^{\circ} 12^{\prime} 45.76^{\prime \prime} \mathrm{N}, 77^{\circ} 22^{\prime} 42.04^{\prime \prime} \mathrm{E}\right)$ and an air temperature of $27^{\circ} \mathrm{C}$.

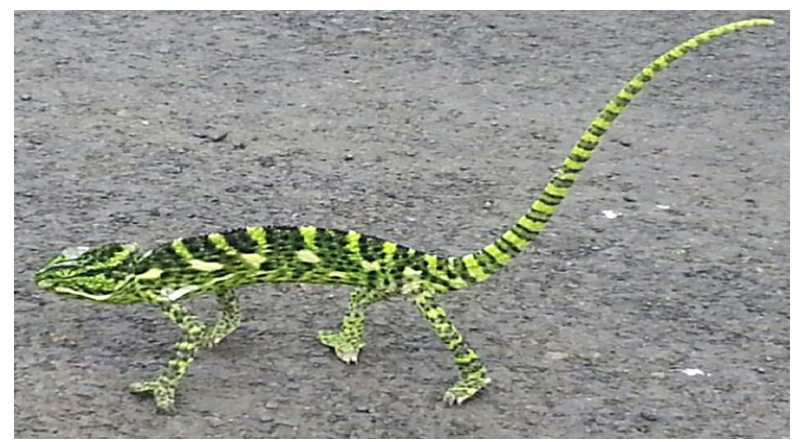

Chandra and Gajbe (2005) documented the species from Seoni, Jabalpur, Chhindwara, and Narsinghpur. Ramakrishna et al. (2006) recorded it from Satpura and Pench National Parks.

Keeled Grass Skink, Eutropis cf. carinata (Schneider 1801) (Mabuyidae) LC - We encountered this species on the campus of Barkatullah University, Bhopal in June 2014 at an elevation of $479 \mathrm{~m}\left(23^{\circ} 12^{\prime} 21.14\right.$ ”N, $\left.77^{\circ} 26^{\prime} 51.52^{\prime \prime} \mathrm{E}\right)$ at an air temperature of $29^{\circ} \mathrm{C}$.

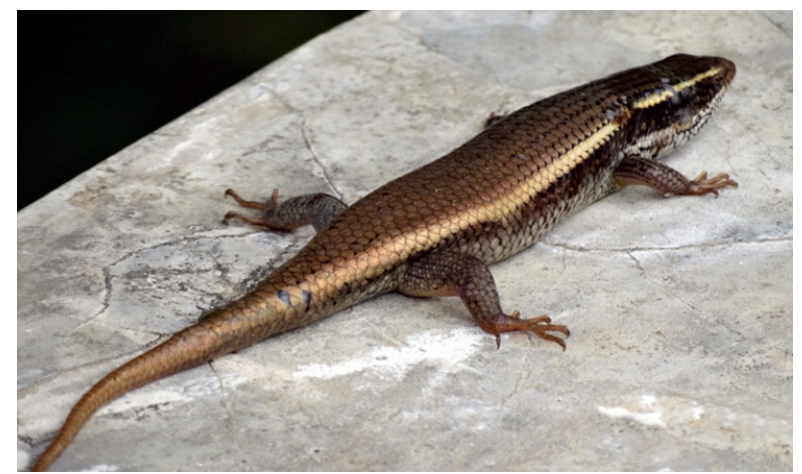

Chandra and Gajbe (2005) reported the species from various districts of Madhya Pradesh (Dindori, Jabalpur, Mandla, Seoni and Shivpuri). Ramakrishna et al. (2006) recorded it from Kanha, Madhav, Pench, and Satpura National Parks. Chandra et al. (2008) documented it from the Kanha Tiger Reserve. 
Bronze Skink, Eutropis cf. macularia (Blyth 1853) (Mabuyidae) NE - We recorded this species in JuneSeptember 2014 and 2015 in residential areas at Barkatullah University, the Shymala Hills, BHEL, and Bagmugalia at elevations of $473-523 \mathrm{~m}\left(23^{\circ} 11^{\prime} 37.97^{\prime \prime}-23^{\circ} 13^{\prime} 45.22^{\prime \prime} \mathrm{N}\right.$, $\left.77^{\circ} 23^{\prime} 2.17^{\prime \prime}-77^{\circ} 28^{\prime} 41.21^{\prime \prime} \mathrm{E}\right)$ and ambient temperatures of $17-28^{\circ} \mathrm{C}$.

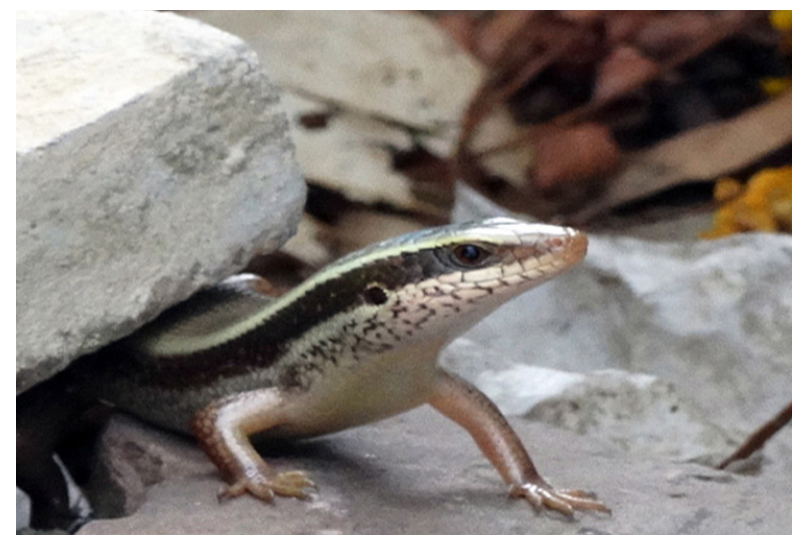

Chandra and Gajbe (2005) reported this species from Mandla and Jabalpur. Ramakrishna et al. (2006) recorded it from Kanha National Park. Chandra et al. (2008) documented its presence in the Kanha Tiger Reserve.

\section{White-spotted Supple Skink, Lygosoma albopunctata} (Gray 1846) (Lygosomidae) NE - We encountered this species on the campus of Barkatullah University, Bhopal in August 2015 at an elevation of $487 \mathrm{~m}\left(23^{\circ} 12^{\prime} 17.30^{\prime \prime} \mathrm{N}\right.$, $\left.77^{\circ} 26^{\prime} 56.28^{\prime \prime} \mathrm{E}\right)$ and an ambient temperature of $26^{\circ} \mathrm{C}$.

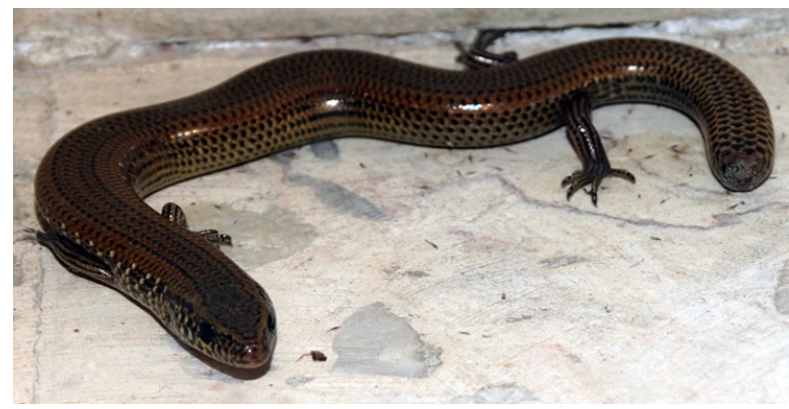

Ramakrishna et al. (2006) recorded the species from Kanha National Park. Chandra et al. (2008) reported it from the Kanha Tiger Reserve.

Lined Supple Skink, Lygosoma lineata (Gray 1839) (Lygosomidae) LC - We found this species in residential areas of Bherkheda in July 2014 at an elevation of $476 \mathrm{~m}$ $\left(23^{\circ} 13^{\prime} 3.03^{\prime \prime} \mathrm{N}, 77^{\circ} 28^{\prime} 46.47^{\prime \prime} \mathrm{E}\right)$ and an ambient air temperature of $27^{\circ} \mathrm{C}$.

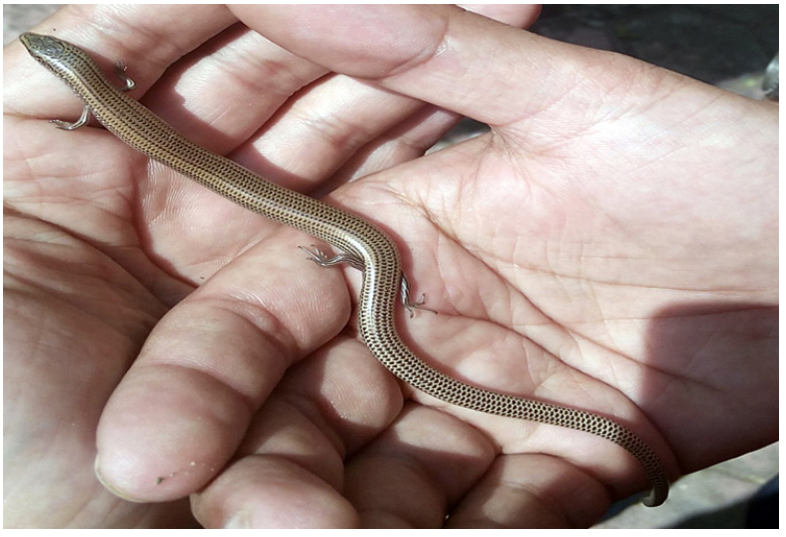

Uetz et al. (2018) indicated that the species is endemic to India and occurs in Bombay, Gujarat, Madhya Pradesh, Tamil Nadu, Maharashtra, Karnataka, and Jharkhand.

Punctate Supple Skink, Lygosoma punctata (Gmelin 1799) (Lygosomidae) NE - We recorded this species from Saket Nagar and BHEL in July 2014 and August 2015 at elevations

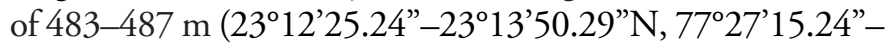
$77^{\circ} 28^{\prime} 58.76^{\prime \prime} \mathrm{E}$ ) and air temperatures of $19-22^{\circ} \mathrm{C}$.

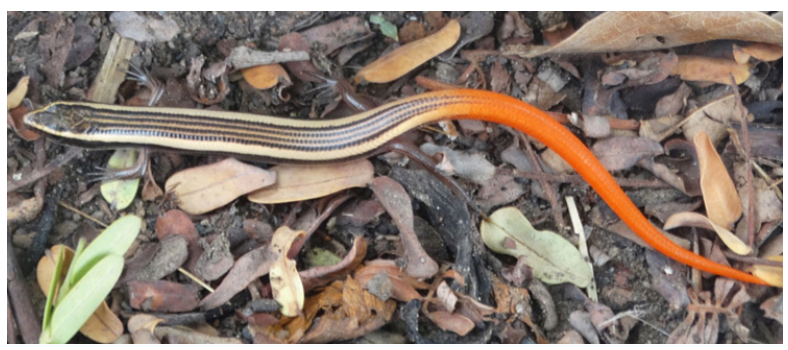

Ramakrishna et al. (2006) recorded the species from Madhav National Park. Chandra et al. (2008) reported it from the Kanha Tiger Reserve.

Bengal Monitor, Varanus bengalensis (Daudin 1802) (Varanidae) LC - We recorded this species near residential areas of Bherkheda and from the campus of Barkatullah University in July 2014 and August 2015 at elevations of

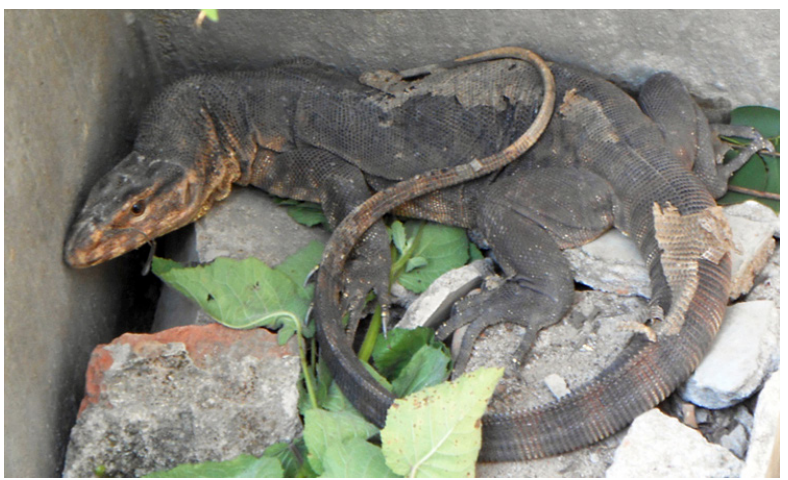




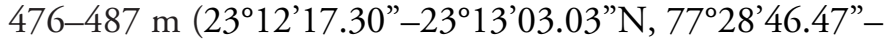
$77^{\circ} 26^{\prime} 56.28^{\prime \prime} \mathrm{E}$ ) and air temperatures of $23-27^{\circ} \mathrm{C}$.

Vyas and Singh (2004) recorded this species from the catchment area of the Gandhi Sagar Reservoir. Chandra and Gajbe (2005) listed it from Dindori, Jabalpur, Mandla, Morena, Seoni, and Shivpuri. Ramakrishna et al. (2006) recorded the species from Kanha, Pench, and Van Vihar National Parks. Chandra et al. (2008) reported it from the Kanha Tiger Reserve.

\section{Common Sand Boa, Eryx conicus (Schneider 1801)} (Erycidae) NE - We recorded this species from the catchment area of the Kaliyasote Dam, the Shymala Hills, and the campus of Barkatullah University in June and August 2014 and July-September 2015 at elevations of 483-535 m (231 $11^{\prime} 28.66^{\prime \prime}-23^{\circ} 13^{\prime} 49.36^{\prime \prime} \mathrm{N}, 77^{\circ} 23^{\prime} 13.57^{\prime \prime}-$ $77^{\circ} 27^{\prime} 20.66^{\prime \prime} \mathrm{E}$ ) and air temperatures of $21-28^{\circ} \mathrm{C}$.

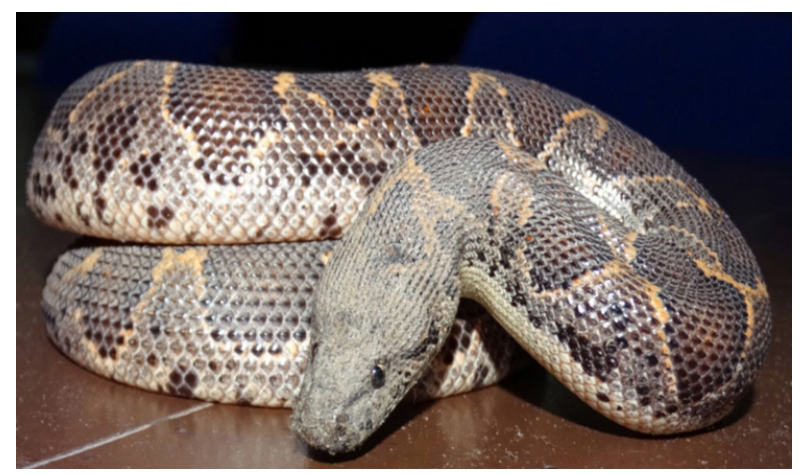

Chandra and Gajbe (2005) documented the species from Jabalpur, Seoni, Mandsaur, Ratlam, Jhabua, Shajapur, Ujjain, Dewas, Indore, and Dhar. Ramakrishna et al. (2006) recorded it from Pench National Park.

Red Sand Boa, Eryx johnii (Russell 1801) (Erycidae) NE - We recorded this species on the Kolar Road near Shahpura in August 2015 at an elevation of $485 \mathrm{~m}\left(23^{\circ} 10^{\prime} 21.11^{\prime \prime} \mathrm{N}\right.$, $\left.77^{\circ} 25^{\circ} 00.64^{\prime \prime} \mathrm{E}\right)$ and an ambient air temperature of $25^{\circ} \mathrm{C}$.

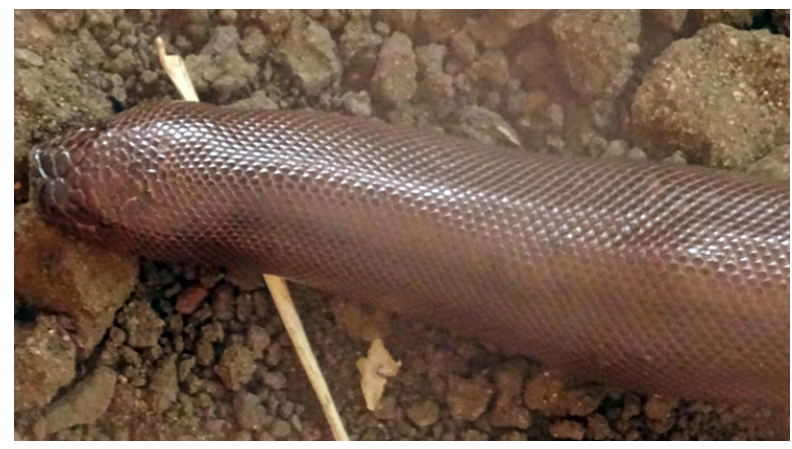

Chandra and Gajbe (2005) documented the occurrence of this species from Seoni, Dindori, Mandsaur, Ratlam, Jhabua, Shajapur, Ujjain, Dewas, Indore, and Dhar. Ramakrishna et al. (2006) reported it from Pench National Park.
Indian Rock Python, Python molurus (Linnaeus 1758) (Pythonidae) NE - We observed this species at the catchment areas of the Kaliyasote Dam and the Lower Lake in September 2014 and July 2015, respectively, at elevations of

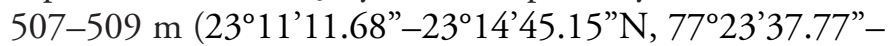
$77^{\circ} 24^{\prime} 30.22^{\prime \prime} \mathrm{E}$ ) and air temperatures of $26-27^{\circ} \mathrm{C}$.

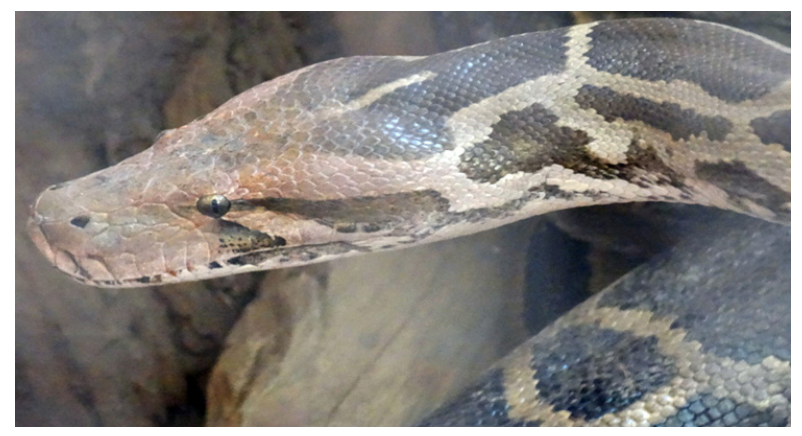

Chandra and Gajbe (2005) recorded this species from Dindori, Jabalpur, Mandla, Morena, Seoni, Jhabua, Ujjain, Dewas, Indore, and Dhar. Ramakrishna et al. (2006) noted its presence in Kanha, Pench, and Satpura National Parks. Chandra et al. (2008) listed the species from the Kanha Tiger Reserve.

Banded Racer, Argyrogena fasciolata (Shaw 1802) (Colubridae) NE - We recorded this species in July 2014 and August 2015 near the Katra Hills and Barkatullah University,

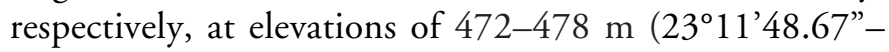
$\left.23^{\circ} 12^{\prime} 7.89^{\prime \prime} \mathrm{N}, 77^{\circ} 27^{\prime} 25.544^{\prime \prime}-77^{\circ} 28^{\prime} 19.08^{\prime \prime} \mathrm{E}\right)$ and air temperatures of $22-24^{\circ} \mathrm{C}$.

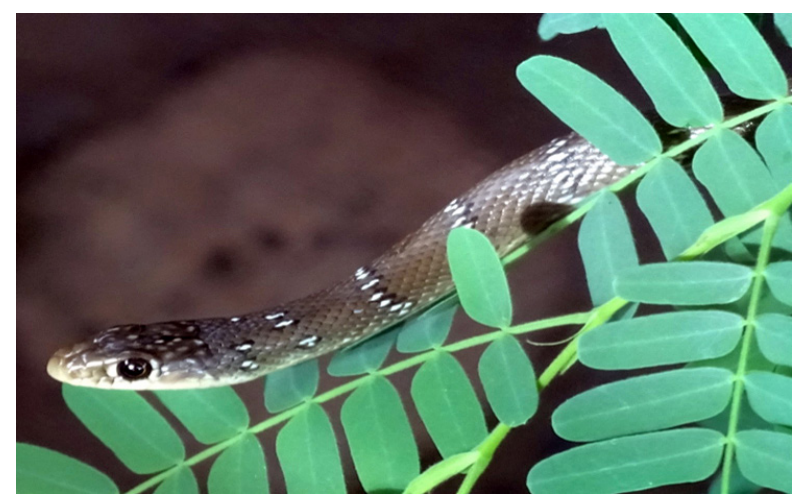

Chandra and Gajbe (2005) reported this species from Gwalior, Jabalpur, Mandla, Ujjain, Dewas, and Indore. Ramakrishna et al. (2006) listed it from Kanha National Park. Chandra et al. (2008) recorded its presence in the Kanha Tiger Reserve.

\section{Trinket Snake, Coelognathus helena (Daudin 1803)} (Colubridae) NE - We recorded this species from the catchment area of the Kerwa Dam in August 2014 at an elevation of $508 \mathrm{~m}\left(23^{\circ} 12^{\prime} 00.17^{\prime \prime} \mathrm{N}, 77^{\circ} 21^{\prime} 59.34\right.$ 'E) and an ambient air temperature of $25^{\circ} \mathrm{C}$. 


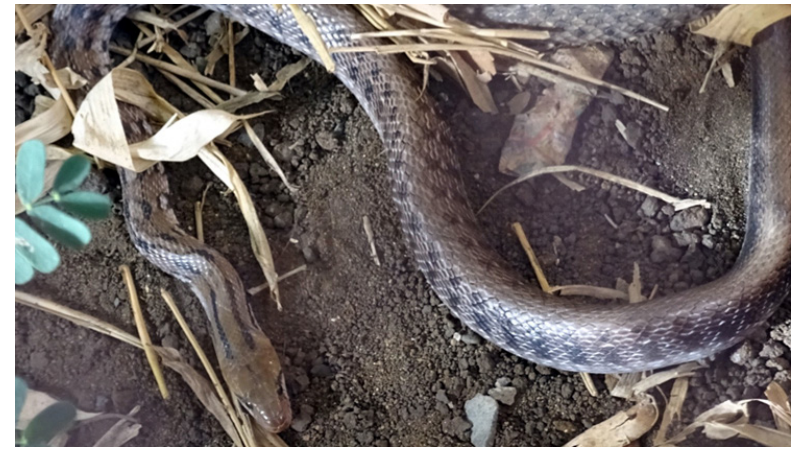

Chandra and Gajbe (2005) listed this species form various districts of Madhya Pradesh (Jabalpur, Seoni, Mandsaur, Ratlam, Shajapur, Ujjain, Dewas, Indore, Dhar). Ramakrishna et al. (2006) recorded it from Pench National Park. Chandra et al. (2008) noted its presence in the Kanha Tiger Reserve.

Common Bronze-backed Treesnake, Dendrelaphis tristis (Daudin 1803) (Colubridae) NE - We observed this species in the catchment area of the Kerwa Dam in September 2014 at an elevation of $521 \mathrm{~m}\left(23^{\circ} 10^{\prime} 10.69^{\prime \prime} \mathrm{N}\right.$, $\left.77^{\circ} 22^{\prime} 43.29^{\prime \prime} \mathrm{E}\right)$ at an air temperature of $21^{\circ} \mathrm{C}$.

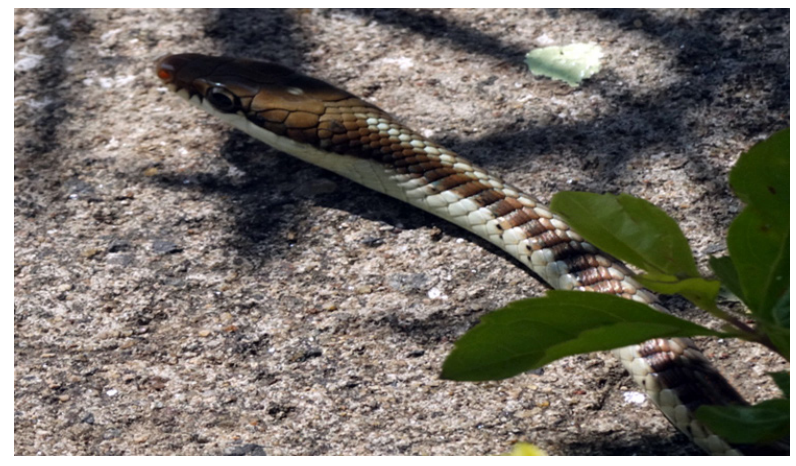

Ramakrishna et al. (2006) documented the species from Pench National Park. Chandra et al. (2008) recorded it from the Kanha Tiger Reserve.

Common Wolfsnake, Lycodon aulicus (Linnaeus 1758) (Colubridae) NE - We observed this species near the Minal Residency at an elevation of 498 m (23 ${ }^{\circ} 15^{\prime} 45.54$ ”N,

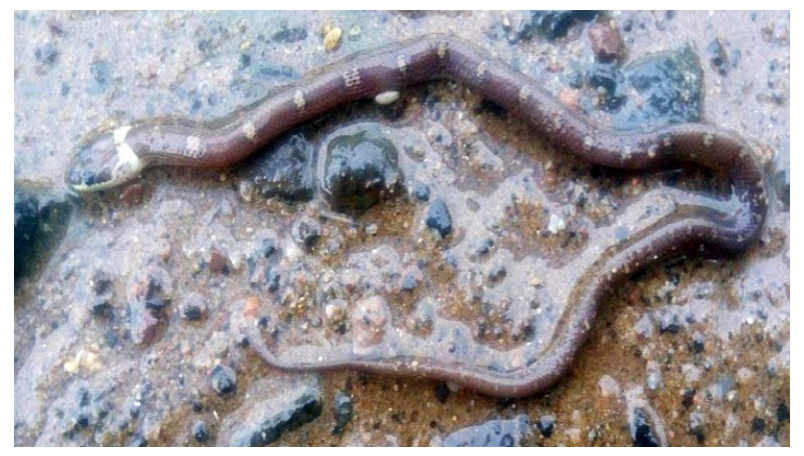

$\left.77^{\circ} 27^{\prime} 25.83^{\prime \prime} \mathrm{E}\right)$ in July 2014 and an ambient temperature of $28{ }^{\circ} \mathrm{C}$.

Chandra and Gajbe (2005) recorded this species from Balaghat, Dindori, Mandsaur, Ratlam, Shajapur, Ujjain, Dewas, Indore, and Dhar. Ramakrishna et al. (2006) documented the species from Pench and Kanha National Parks. Chandra et al. (2008) reported it in the Kanha Tiger Reserve.

Banded Kukri Snake, Oligodon arnensis (Shaw 1802) (Colubridae) NE - We recorded this species from the Katra Hills and on the Barkatullah University campus at elevations of $481-484 \mathrm{~m}\left(23^{\circ} 12^{\prime} 9.30^{\prime \prime}-23^{\circ} 12^{\prime} 25.65^{\prime \prime} \mathrm{N}, 77^{\circ} 26^{\prime} 50.744^{\prime \prime}-\right.$ $\left.77^{\circ} 29^{\prime} 53.19^{\prime \prime} \mathrm{E}\right)$ in June-September 2014 and 2015 at air temperatures of $20-28^{\circ} \mathrm{C}$.

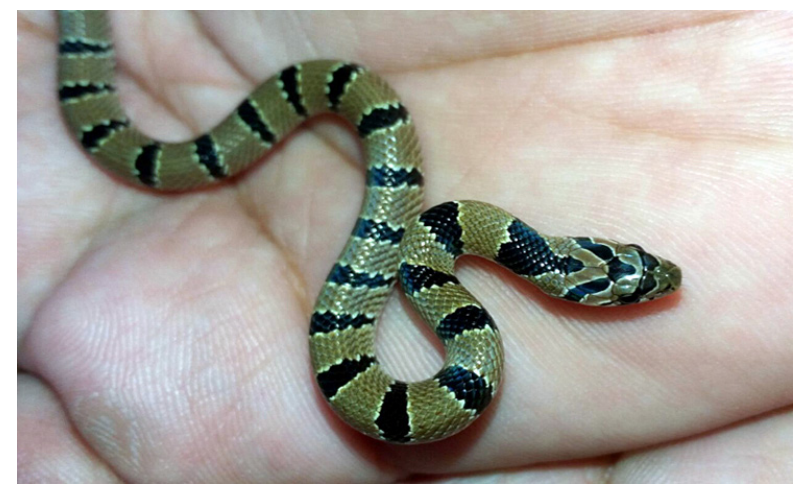

Chandra and Gajbe (2005) reported the species from Jabalpur, Ujjain, Dewas, and Indore.

Indian Ratsnake, Ptyas mucosa (Linnaeus 1758) (Colubridae) NE - We recorded this species from Barkatullah University, Habibganj Depot, Shahpura, and Saket Nagar in June-September 2014 and 2015 at elevations of $475-504 \mathrm{~m}\left(23^{\circ} 11^{\prime} 40.95^{\prime \prime}-23^{\circ} 12^{\prime} 59.32^{\prime \prime} \mathrm{N}\right.$, $\left.77^{\circ} 25^{\prime} 36.58^{\prime \prime}-77^{\circ} 29^{\prime} 29.42^{\prime \prime} \mathrm{E}\right)$ at ambient temperatures of $21-30^{\circ} \mathrm{C}$.

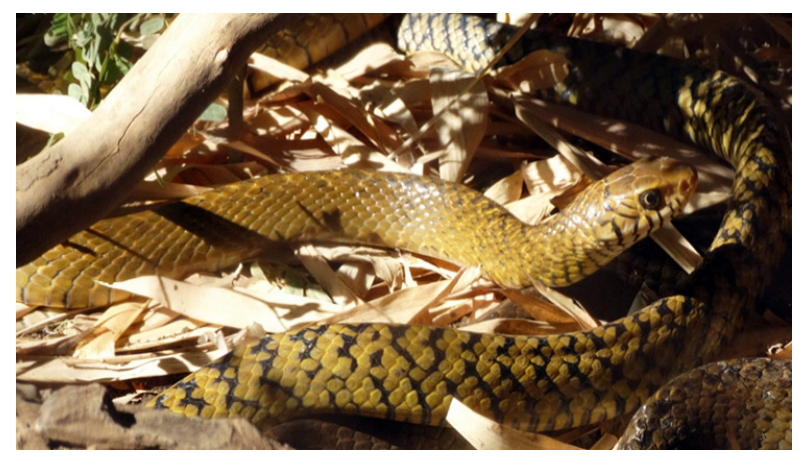

Chandra and Gajbe (2005) reported the species from Dindori, Jabalpur, Mandsaur, Seoni, Mandla, Ratlam, Jhabua, Shajapur, Ujjain, Dewas, Indore, Dhar, and Shivpuri. Ramakrishna et al. (2006) recorded the species from Pench 
and Kanha National Parks. Chandra et al. (2008) noted its presence in the Kanha Tiger Reserve.

\section{Buff-striped Keelback, Amphiesma stolatum (Linnaeus} 1758) (Natricidae) NE - We recorded this species from the Barkatullah University campus, the Katra Hills, and the catchment area of the Kerwa Dam in July-September 2014 and 2015 at elevations of 471-478 m (23 $10^{\circ} 40.89^{\prime \prime}-$ $23^{\circ} 11^{\prime} 48.67^{\prime \prime} \mathrm{N}, 77^{\circ} 21^{\prime} 50.99^{\prime \prime}-77^{\circ} 28^{\prime} 42.39^{\prime \prime} \mathrm{E}$ ) and ambient temperatures of $26-32{ }^{\circ} \mathrm{C}$.

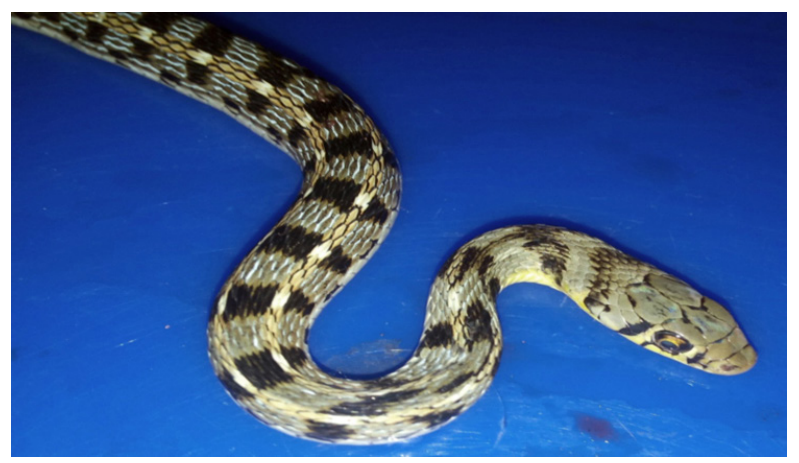

Chandra and Gajbe (2005) reported the presence of this species in the Seoni, Dindori, Mandsaur, Ratlam, Jhabua, Shajapur, Ujjain, Dewas, Indore, and Dhar Districts. Ramakrishna et al. (2006) recorded it from Pench National Park. Chandra et al. (2008) listed it from the Kanha Tiger Reserve.

\section{Checkered Keelback, Xenochrophis piscator (Schneider} 1799) (Natricidae) NE - We recorded this species from the campus of Barkatullah University, Alkapuri, the Katara Hills, Shahpura, and the Kaliyasote Dam in June-September 2014 and 2015 at elevations of $477-512 \mathrm{~m}\left(23^{\circ} 10^{\prime} 40.57^{\prime \prime}-\right.$ $23^{\circ} 12^{\prime} 58.00^{\prime \prime} \mathrm{N}, 77^{\circ} 25^{\prime} 17.32^{\prime \prime}-77^{\circ} 29^{\prime} 44.66^{\prime \prime}$ ) at air temperatures of $23-30^{\circ} \mathrm{C}$.

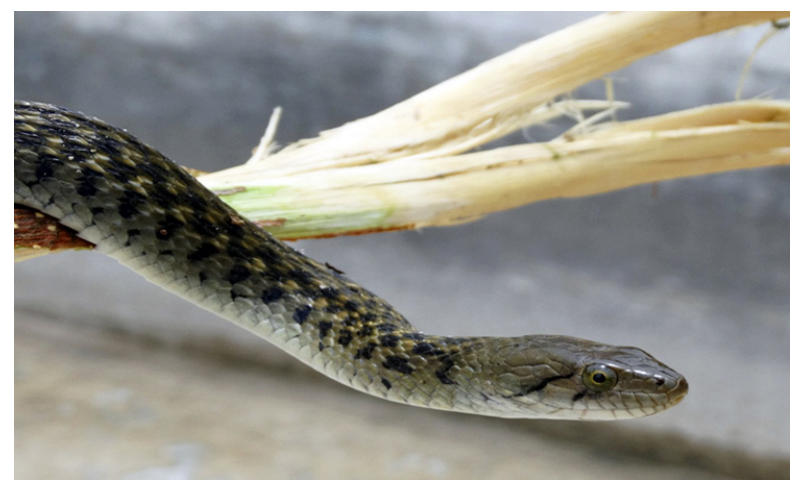

Chandra and Gajbe (2005) listed the species from Dindori, Jabalpur, Mandsaur, Seoni, Ratlam, Jhabua, Shivpuri, Shajapur, Ujjain, Dewas, Indore, and Dhar. Ramakrishna et al. (2006) reported it from Pench and Madhav National Parks. Chandra et al. (2008) noted its presence in the Kanha Tiger Reserve.
Common Krait, Bungarus caeruleus (Schneider 1801) (Elapidae) NE - We observed this species at BHEL and Saket Nagar in September 2014 and August 2015,

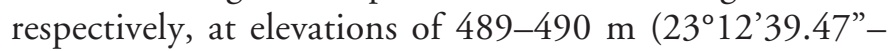
$\left.23^{\circ} 14^{\prime} 43.26^{\prime \prime} \mathrm{N}, 77^{\circ} 27^{\prime} 06.31^{\prime \prime}-77^{\circ} 28^{\prime} 21.41^{\prime \prime} \mathrm{E}\right)$ and ambient air temperatures of $25-26^{\circ} \mathrm{C}$.

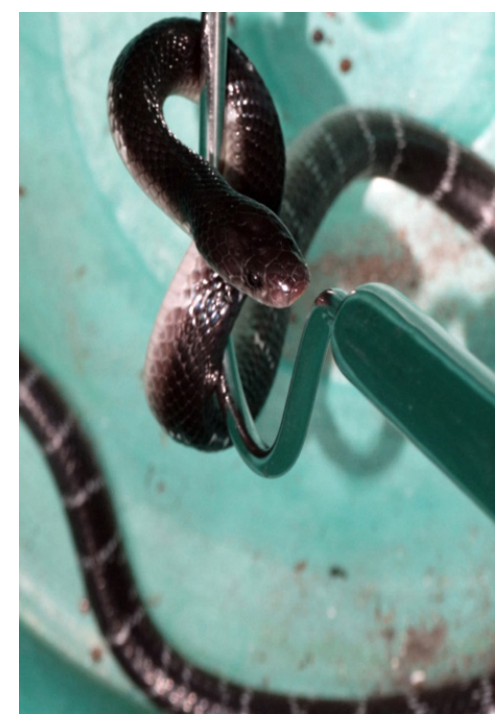

Chandra and Gajbe (2005) listed this species from Dindori, Jabalpur, Mandsaur, Seoni, Ratlam, Jhabua, Shivpuri, Shajapur, Ujjain, Dewas, Indore, Mandla, and Dhar. Ramakrishna et al. (2006) reported the species from Pench and Kanha National Parks. Chandra et al. (2008) reported its occurrence from the Kanha Tiger Reserve.

Common Indian Cobra, Naja naja (Linnaeus 1758) (Elapidae) NE - We recorded this species from Barkatullah University, Baghsewania, and near the Idgah and Shymala Hills in July-September 2014 and 2015 at elevations of $474-574 \mathrm{~m}\left(23^{\circ} 11^{\prime} 58.53^{\prime \prime}-23^{\circ} 16^{\prime} 21.00^{\prime \prime} \mathrm{N}, 77^{\circ} 22^{\prime} 39.58^{\prime \prime}-\right.$ $77^{\circ} 27^{\prime} 37.19^{\prime \prime} \mathrm{E}$ ) and air temperatures of $20-28^{\circ} \mathrm{C}$.

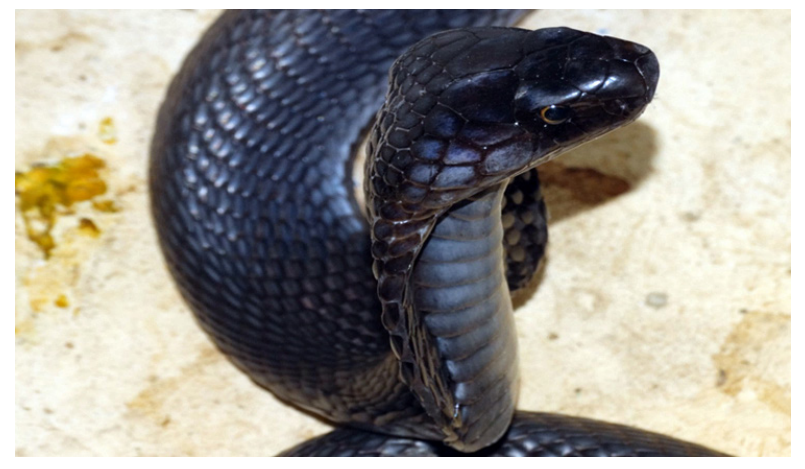

Chandra and Gajbe (2005) reported the species from Dindori, Gwalior, Jabalpur, Mandla, Seoni, Mandsaur, Ratlam, Jhabua, Shajapur, Ujjain, Dewas, Indore, and Dhar. Ramakrishna et al. (2006) listed it from Pench and Kanha 
National Parka. Chandra et al. (2008) noted the presence of the species in the Kanha Tiger Reserve.

King Cobra, Ophiophagus hannab (Cantor 1836) (Elapidae) VU - We observed this species in Van Vihar National Park at an elevation of $526 \mathrm{~m}\left(23^{\circ} 13^{\prime} 40.47^{\prime \prime} \mathrm{N}\right.$, $\left.77^{\circ} 21^{\prime} 38.92^{\prime \prime} \mathrm{E}\right)$ where it was kept in captivity to protect it from smugglers.

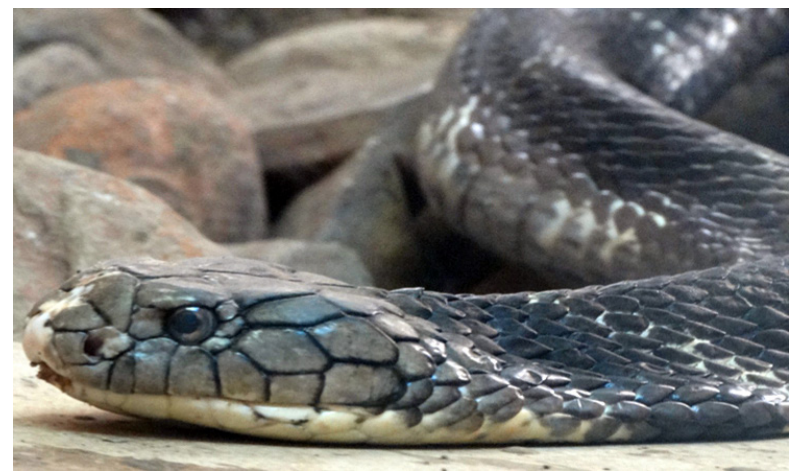

Stuart et al. (2012) noted that this species is widely distributed throughout southern and southeastern Asia.

\section{Brahminy Blindsnake, Indotyphlops braminus (Daudin} 1803) (Typhlopidae) NE - We recorded this species from residential areas of Saket Nagar in June 2014 and August 2015 and from Baghsewania in September 2015 at elevations of $370-477 \mathrm{~m}\left(23^{\circ} 11^{\prime} 58.53^{\prime \prime}-23^{\circ} 12^{\prime} 39.47^{\prime \prime} \mathrm{N}, 7^{\circ} 27^{\prime} 06.31^{\prime \prime}-\right.$ $\left.77^{\circ} 27^{\prime} 37.19^{\prime \prime} \mathrm{E}\right)$ and air temperatures of $18-26^{\circ} \mathrm{C}$.

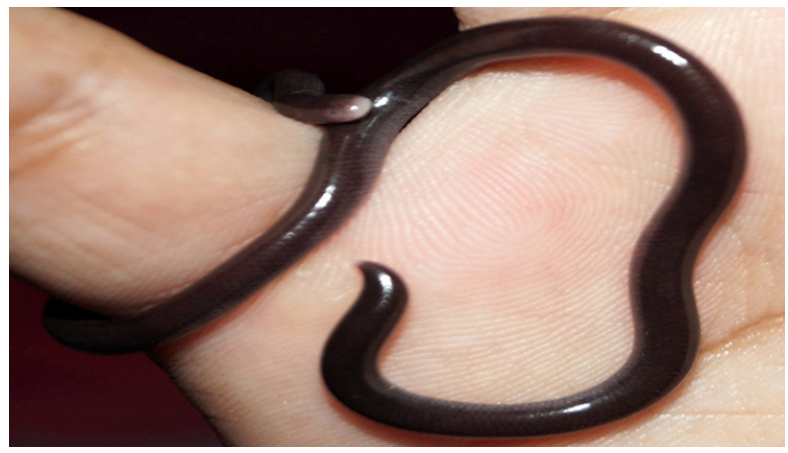

Chandra and Gajbe (2005) listed this species from Balaghat, Hoshangabad, Mandsaur, Ratlam Jhabua, Shajapur, Ujjain, Dewas, Indore, Dh r, Dindori, Jabalpur, Mandla, and Seoni. Ramakrishna et al. (2006) reported it from Pench, Kanha, and Satpura National Parks.

\section{Russell's Viper, Daboia russelii (Shaw and Nodder 1797)}

(Viperidae) NE - We recorded this species near Kohefiza, on the Barkatullah University campus, and at Saket Nagar in June 2014 and August and September 2015 at elevations of $460-515 \mathrm{~m}\left(23^{\circ} 12^{\prime} 5.49^{\prime \prime}-23^{\circ} 12^{\prime} 22.45^{\prime \prime} \mathrm{N}, 77^{\circ} 20^{\prime} 57.21^{\prime \prime}-\right.$ $\left.77^{\circ} 27^{\prime} 55.18^{\prime \prime} \mathrm{E}\right)$ at air temperatures of $19-28^{\circ} \mathrm{C}$.

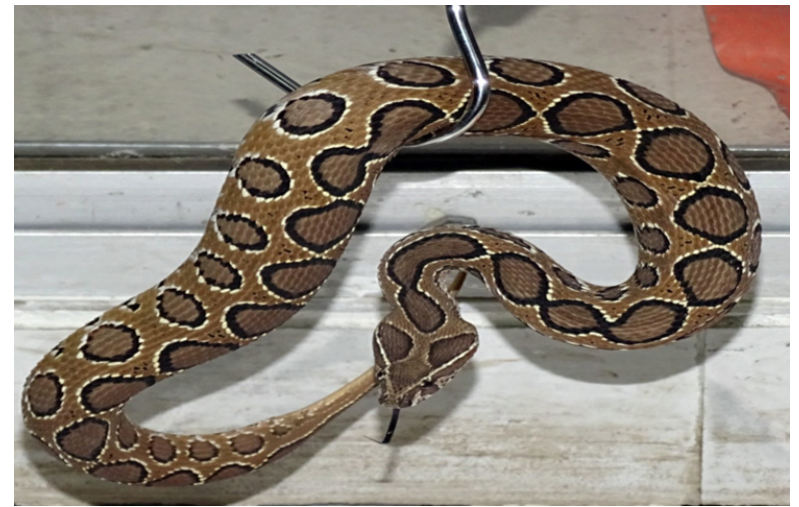

Chandra and Gajbe (2005) listed this species from Dindori, Mandla, Seoni, Mandsaur, Ratlam, Jhabua, Shajapur, Ujjain, Dewas, Indore, and Dhar. Ramakrishna et al. (2006) reported its occurrence in Pench, Kanha, and Satpura National Parks. Chandra et al. (2008) recorded its presence in the Kanha Tiger Reserve.

Saw-scaled Viper, Echis carinatus (Schneider 1801) (Viperidae) NE - We recorded this species near Alkapuri in August 2014 at an elevation of $482 \mathrm{~m}\left(23^{\circ} 13^{\prime} 01.82^{\prime \prime} \mathrm{N}\right.$, $\left.77^{\circ} 27^{\prime} 55.18^{\prime \prime} \mathrm{E}\right)$ and an air temperature of $18^{\circ} \mathrm{C}$.

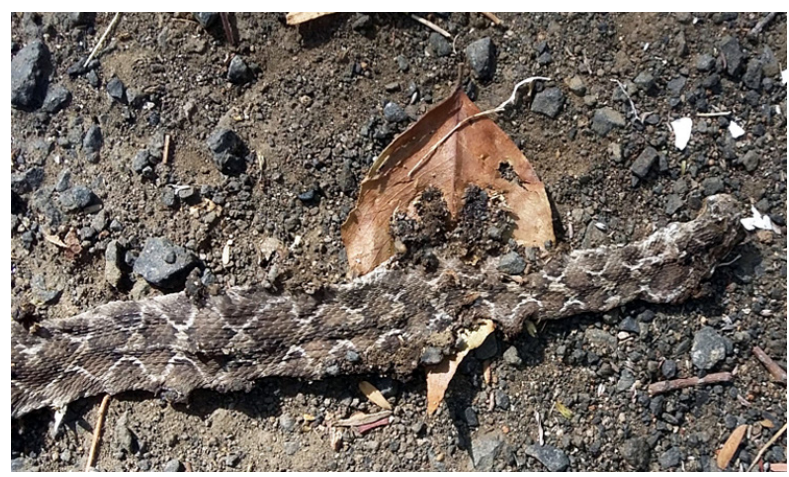

Chandra and Gajbe (2005) recorded the species from Jabalpur, Seoni, Ujjain, Dhar, and Jhabua. Ramakrishna et al. (2006) noted its occurrence in Pench National Park. Chandra et al. (2008) reported it from the Kanha Tiger Reserve.

\section{Discussion}

All of our observations were at ambient temperatures of $17-34^{\circ} \mathrm{C}$, and we did not encounter any reptiles at temperatures below or above that range. Consequently, we did not conduct surveys during the summer, when temperatures frequently exceed $40{ }^{\circ} \mathrm{C}$, or in the winter, when temperatures often fall below $15^{\circ} \mathrm{C}$, conditions that are incompatible with extensive levels of activity by ectothermic reptiles.

Localities where we recorded reptiles are illustrated in Fig. 2. Of 34 species observed, five (Crocodylus palustris, Gavialis gangeticus, Lissemys punctata, Nilssonia hurum, Pangshura tectum) were aquatic whereas the other 30 species were primar- 


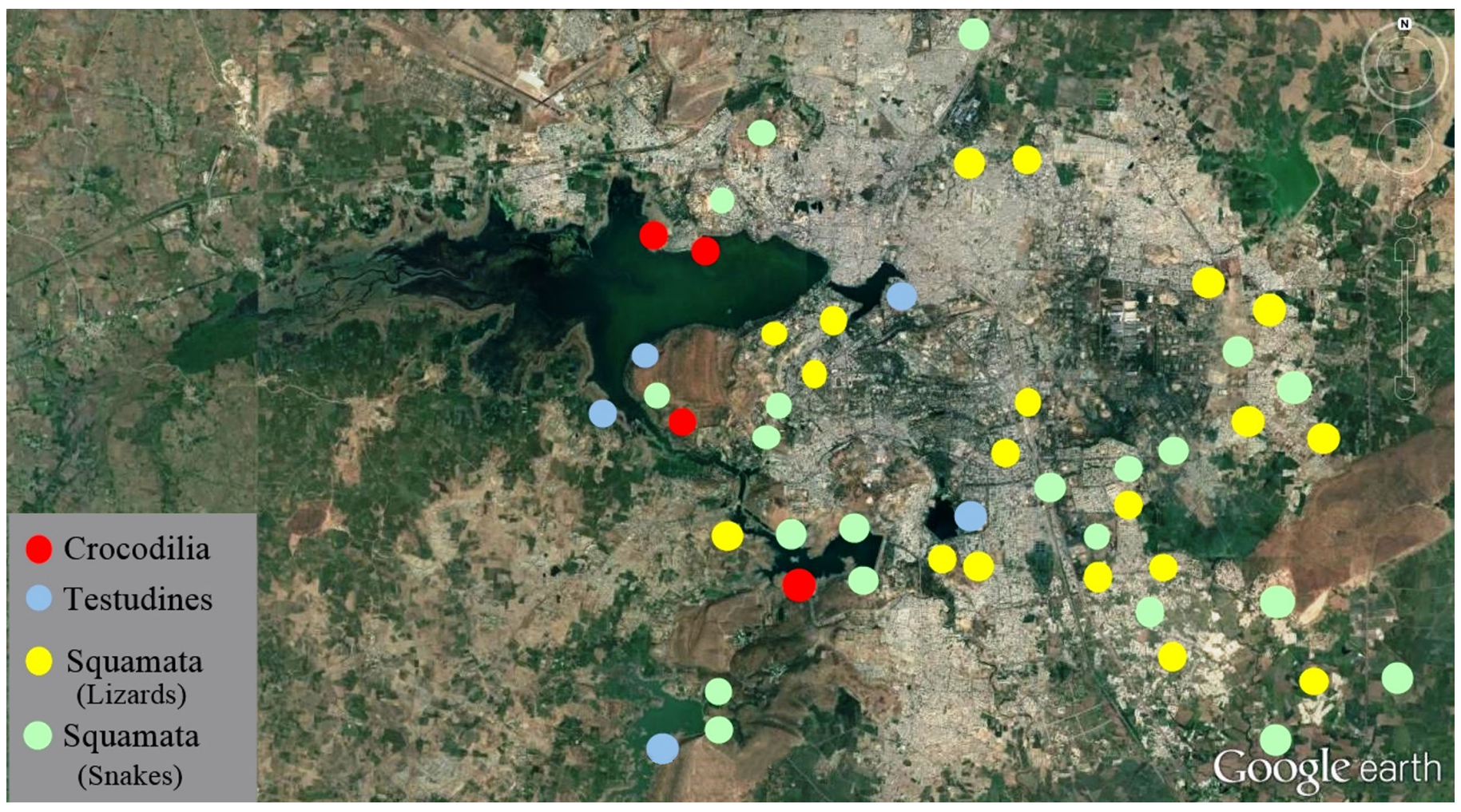

Fig. 2. Google Earth ${ }^{\odot}$ map of the Bhopal District, Madhya Pradesh, India showing localities where reptiles were encountered.

ily terrestrial. We encountered four species of snakes (Ptyas mucosa, Xenochrophis piscator, Amphiesma stolata, Naja naja) with some regularity, whereas five species (Python molurus, Eryx johnii, Echis carinatus, Dendrelaphis tristis, Bungarus caeruleus, Lycodon aulicus) were rarely seen.

When we compared the reptiles we observed in the Bhopal Region to those recorded for other parts of Madhya Pradesh (76 species listed by Chandra and Gajbe 2005), all but two (Hemidactylus frenatus, Ophiophagus hannah) species have been recorded from the state excluding two (Ophiophagus hannah) kept in Van Vihar National Park, Bhopal (detained from the smuggler) and Hemidactylus frenatus.

Twenty-two of the species encountered had not been evaluated for the IUCN Red List (2017), seven were of Least Concern, three were Vulnerable, and one (Gavialis gangeticus) was Critically Endangered (note that one observation could not be identified to species). Of the 33 identified species we observed, 14 (Crocodylus palustris, Gavialis gangeticus, Nilssonia gangeticus, Lissemys punctata, Pangshura tectum, Varanus bengalensis, Nilssonia hurum, Python molurus, Chamaeleo zeylanicus, Ptyas mucosa, Xenochrophis piscator, Naja naja, Ophiophagus hannah, Daboia russelii) are protected under Schedules I and II of the Indian Wildlife Act 1972 (imposing absolute protection and violations eliciting high penalties). The remaining 20 species are protected under schedule IV of the Indian Wildlife Protection Act 1972 (also protected but penalties are less). That the conservation status of so many of these species has not been assessed through- out their ranges is of considerable concern, as anthropogenic threats are severe and increasing throughout southern Asia.

Most of the factors threatening populations of reptiles in the Bhopal Region of Madhya Pradesh (e.g., Manhas et al. 2015a, 2015b, 2016a, 2016b) emanate from habitat loss, the greatest extent of which is attributable to the conversion of natural habitats for purposes of agriculture and urbanization. Crocodilians and turtles also are exploited for meat and, in the case of the former, their hides. Many species of squamates are threatened by vehicular traffic. However, many reptiles - especially snakes are killed as a result of fear and superstitions. Declining reptilian populations warrant greater conservation efforts, with a particularly urgent need to create an awareness among local human populations regarding the importance of maintaining viable ecosystems in which reptiles play major roles.

\section{Literature Cited}

Aengals, R., S.V.M. Kumar, and M.J. Palot. 2011. Updated Checklist of Indian Reptiles (http://www.lacertilia.de/AS/Bibliografie/BIB_6715.pdf).

Chandra, K. 2009. Reptilia, pp. 117-128. In: Director, Zoological Survey of India (ed.), Fauna of Pachmarhi Biosphere Reserve (Madhya Pradesh). Conservation Area Series 39. Zoological Survey of India, Kolkata.

Chandra K. and U.P. Gajbe. 2003. New record of Ocellate Shield Tail Uropeltis ocellata (Beddome), (Uropeltidae) from Pachmarhi Biosphere Reserve, Madhya Pradesh. Cobra 52: 15-16.

Chandra K. and U.P. Gajbe. 2005. An inventory of herpetofauna of Madhya Pradesh and Chhattisgarh. Zoos' Print Journal 20: 1812-1819.

Chandra, K., R.C. Sharma, N. Nagpure, and D.K. Nema. 2008. Reptiles of Kanha Tiger Reserve, Madhya Pradesh. Records of the Zoological Survey of India 108: 49-83.

Daniel, J.C. 2002. The Book of Indian Reptiles and Amphibians. Oxford University 
Press, Oxford, United Kingdom.

Das, I. 1988. New locality record for the Indian Peacock Soft shell Turtle Trionyx hurum. Journal of the Bombay Natural History Society 84: 691-692.

Fellows, S. 2014. Species diversity of snakes in Pachmarhi Biosphere Reserve. Entomology, Ornithology \& Herpetology 4: 136 (4 pp.)

Ingle, M. 2002. Ecology and status of the ophiofauna of eight districts of Malwa region of Madhya Pradesh. Cobra 50: 1-17.

IUCN. 2017. The IUCN Red List of Threatened Species. Version 2017-3 (www. iucnredlist.org).

Kalalurasam, V., B. Rathinasabapathy, P. Tamilarasan, R. Aengals, and G.A.J. Prasanna. 1991. Herpetological survey of Narmada Valley, Madhya Pradesh. Cobra 5: 8-11.

Manhas, A., A. Kotwal, R.R. Wanganeo, and A. Wanganeo. 2015a. Diversity, threats and conservation of herpetofauna in and around Barkatullah University, Bhopal (MP), India. International Journal of Advanced Research 3: 1546-1553.

Manhas, A., R. Raina, and A. Wanganeo. 2015b. Snakes of the Bhopal district, Madhya Pradesh, India with special reference to road mortality. Journal of Research in Biology 5: 1868-1873.

Manhas, A., R. Raina, and A. Wanganeo. 2016a. An assessment of reptilian diversity and their distribution in Jammu and Kashmir state from Jammu city in northern India: A case study. International Journal of Fauna and Biological Studies 3(3): 20-23.

Manhas, A., R. Raina, and A. Wanganeo. 2016b. Natural history and threats of rat snake (Ptyas mucosus, Linnaeus) with special reference to their protection. International Journal of Advance Research in Science, Humanities and Engineering 1(2): 1-6.

Manhas, A., R. Raina, and A. Wanganeo. 2016c. An addition to the reptilian diversity of Barkatullah University campus, Bhopal, Madhya Pradesh, India. International Journal of Pure and Applied Zoology 4: 306-309.

Meshram, P.K. 2010. Diversity of some fauna in National Chambal Sanctuary in Madhya Pradesh, India. Biodiversitas 11(4): 211-215.
Pasha, M.K.S., G. Areendran, K. Sankar, and Q. Qureshi. 2000. A preliminary checklist of snakes of Pench Tiger Reserve, Madhya Pradesh. Cobra 40: 5-8.

Rao, R.J. 1998. Status of crocodiles and freshwater turtles in the Chambal and Ganga River: A comparative analysis. Cobra 33: 31-34.

Ramakrishana, K. Chandra, D.K. Nema, S.C. Ahirwar, and J.R.B. Alfred. 2006. Faunal resources of National Parks of Madhya Pradesh. Conservation Area Series 30: 1-123.

Sanyal, D.P. 1995. Reptilia, pp. 77-83. In: Director, Zoological Survey of India (ed.), Fauna of Indrāvati Tiger Reserve Madhya Pradesh. Fauna of Conservation Areas No. 6. Zoological Survey of India, Kolkata.

Smith, M.A. 1931. Fauna of British India, including Ceylon and Burma. Reptilia and Amphibia. Vol. I-Loricata, Testudines. Trustees of the British Museum, London.

Smith, M.A. 1935. Fauna of British India, including Ceylon and Burma. Reptilia and Amphibia. Vol. II - Sauria. Trustees of the British Museum, London.

Smith, M.A. 1943. Fauna of British India, including the Whole of the Indo-Chinese Sub-region. Reptilia and Amphibia. Vol. III - Serpentes. Trustees of the British Museum, London.

Stuart, B., G. Wongan, L. Grismer, M. Auliya, R.F. Inger, R. Lilley, T. Chan-Ard, N. Thy, T.Q. Nguyen, C. Srinivasulu, and D. Jelic. 2012. Ophiophagus hannah. The IUCN Red List of Threatened Species 2012: e.T177540A1491874 (http://dx.doi.org/10.2305/IUCN.UK.2012-1.RLTS.T177540A1491874.en).

Taigor, S.R. and R.J. Rao. 2010. Habitat features of aquatic animals in the National Chambal Sanctuary, Madhya Pradesh, India. Asian Journal of Experimental Biological Sciences 1: 409-414.

Uetz, P., J. Hallermann, and J. Hošek (eds.). 2018. The Reptile Database (http:// www.reptile-database.org).

Vyas, R. and H. Singh. 2004. Biodiversity survey of Gandhi Sagar Reservoir, Madhya Pradesh. Zoos' Print Journal 19: 1525-1529.

Whitaker R. and Captain A. 2004. Snakes of India. The Field Guide. Draco Books, Chennai, Tamil Nadu, India. 